\title{
Tizanidine May Discriminate between Imidazoline-Receptors and $\alpha_{2}$-Adrenoceptors
}

\author{
Ikunobu Muramatsu and Shigeru Kigoshi \\ Department of Pharmacology, Fukui Medical School, Matsuoka, Fukui 910-11, Japan \\ Received April 27, 1992 Accepted May 21, 1992
}

\begin{abstract}
The selectivity of tizanidine to the imidazoline-receptor and $\alpha_{2}$-adrenoceptor recognized by ${ }^{3} \mathrm{H}$ - $p$-aminoclonidine was examined in rat kidney membranes and was compared with those of other imidazoline compounds. Tizanidine bound to the imidazoline-receptors with approximately 20 times higher affinity than the $\alpha_{2}$-adrenoceptors. The order of relative selectivity to imidazoline receptor was tizanidine $>$ oxymetazoline $>$ clonidine $>$ naphazoline, where clonidine showed an equal affinity to both receptors. Tizanidine may act more potently on the imidazoline-receptors than the $\alpha_{2}$-adrenoceptors.
\end{abstract}

Keywords: Tizanidine, Imidazoline-receptor, $\alpha_{2}$-Adrenoceptor, Kidney (rat)

Tizanidine is an $\alpha_{2}$-adrenoceptor agonist which has an imidazoline ring in its structure and is clinically used as an antispastic drug. Its pharmacological features are similar to those of clonidine, although some differences have been reported $(1,2)$. Recently, clonidine and other imidazoline compounds have been found to act on not only $\alpha_{2}$-adrenoceptors but also imidazoline-receptors; their hypotensive action is in part associated with the imidazoline-receptor located in the medulla oblongata (3-5). Imidazoline-receptors are widely distributed in central and peripheral tissues, and an endogenous clonidine-like substance has been found to have a high affinity to the imidazoline-receptors (5-7). Therefore, it is supposed that the imidazoline-receptors may play an important role in many physiological functions. In the present study, we examined the selectivity of tizanidine to the imidazoline-receptor and $\alpha_{2}$-adrenoceptor of rat kidney membranes and compared it with those of clonidine and other compounds.

\section{MATERIALS AND METHODS}

\section{Membrane preparation}

Male Wistar rats $(300-350 \mathrm{~g})$ were decapitated and the kidneys were rapidly removed. The kidneys were minced in ice-cold $50 \mathrm{mM}$ Tris- $\mathrm{HCl}, 5 \mathrm{mM}$ EDTA (pH 7.7) and then homogenized by a polytron. The homogenate was filtered through 4 layers of silk gauze and centrifuged at $40,000 \times g$ for $13 \mathrm{~min}$. The pellet was resuspended in $50 \mathrm{mM}$ Tris- $\mathrm{HCl}, 25 \mathrm{mM} \mathrm{NaCl}$ buff-

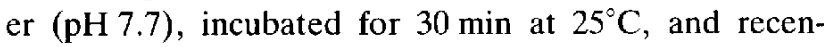
trifuged as described above. The final pellet was resuspended in $50 \mathrm{mM}$ Tris- $\mathrm{HCl}$ buffer $(\mathrm{pH} 7.7)$ and used for the binding assay.

\section{Binding assays}

Incubations were performed in duplicate at $25^{\circ} \mathrm{C}$ for $40 \mathrm{~min}$ in a total volume of $1 \mathrm{ml}$. The incubate consisted of ${ }^{3} \mathrm{H}$-p-aminoclonidine ( ${ }^{3} \mathrm{H}$-PAC), a suspension of kidney membranes (approximately $0.55 \mathrm{mg} / \mathrm{ml}$ ) and either buffer alone or buffer containing a test compound. Non-specific binding was defined by parallel incubations containing $10 \mu \mathrm{M}$ phentolamine. In experiments using adrenaline, all samples contained ascortic acid in a final concentration of $0.01 \%$. Incubations were terminated by vacuum filtration over Whatman $\mathrm{GF} / \mathrm{C}$ filters by using a cell harvester. The filters were washed with ice-cold Tris- $\mathrm{HCl}$; then the filter-bound radioactivity was determined using a scintillation counter (Aloka, Japan). All binding data were analyzed by the weighed least-squares iterative curve fitting program LIGAND, and protein was assayed by the method of Bradford, as shown previously (8).

\section{Drugs}

Drugs were obtained from the following sources: tiza- 
nidine hydrochloride (Sandoz, Tokyo, Japan), clonidine hydrochloride, oxymetazoline hydrochloride, naphazoline hydrochloride, l-adrenaline bitartrate (Nacalai, Kyoto, Japan) and phentolamine mesylate (Ciba-Geigy, Tokyo, Japan). ${ }^{3} \mathrm{H}-p$-Aminoclonidine $\left({ }^{3} \mathrm{H}-\mathrm{PAC}\right.$, specific activity $2153.4 \mathrm{GBq} / \mathrm{mmol}$ ) was purchased from New England Nuclear (Boston, USA).

\section{RESULTS}

The specific binding of ${ }^{3} \mathrm{H}-\mathrm{PAC}(0.1-20 \mathrm{nM})$ was concentration-dependent and saturated at $15-20 \mathrm{nM}$. Scatchard plots of the binding data showed a straight line, suggesting a single class of binding sites $\left(K_{D}=\right.$ $2.17 \pm 0.21 \mathrm{nM}, \mathrm{B}_{\max }=66.5 \pm 2.7 \mathrm{fmol} / \mathrm{mg}$ protein, $\mathrm{n}$
$=4$ ).

Clonidine monophasically displaced the specific binding of $1 \mathrm{nM}{ }^{3} \mathrm{H}-\mathrm{PAC}$, resulting in a single affinity $\left(\mathrm{K}_{\mathrm{i}}=\right.$ $9.20 \pm 1.23 \mathrm{nM}$ ) (Fig. 1). However, tizanidine showed a shallow displacement curve (Fig. 1). Computerized analysis revealed that tizanidine subdivided the binding sites into two populations; the proportion of low affinity sites was $71 \%$. Oxymetazoline and naphazoline also discriminated the two distinct affinity sites with a similar proportion. On the other hand, adrenaline partially displaced the ${ }^{3} \mathrm{H}-\mathrm{PAC}$ binding (Fig. 1), revealing the occurrence of adrenaline-sensitive and insensitive sites (Fig. 1). According to the relative proportions, the affinities of two different sites discriminated by each competing drug are summarized in Table 1.

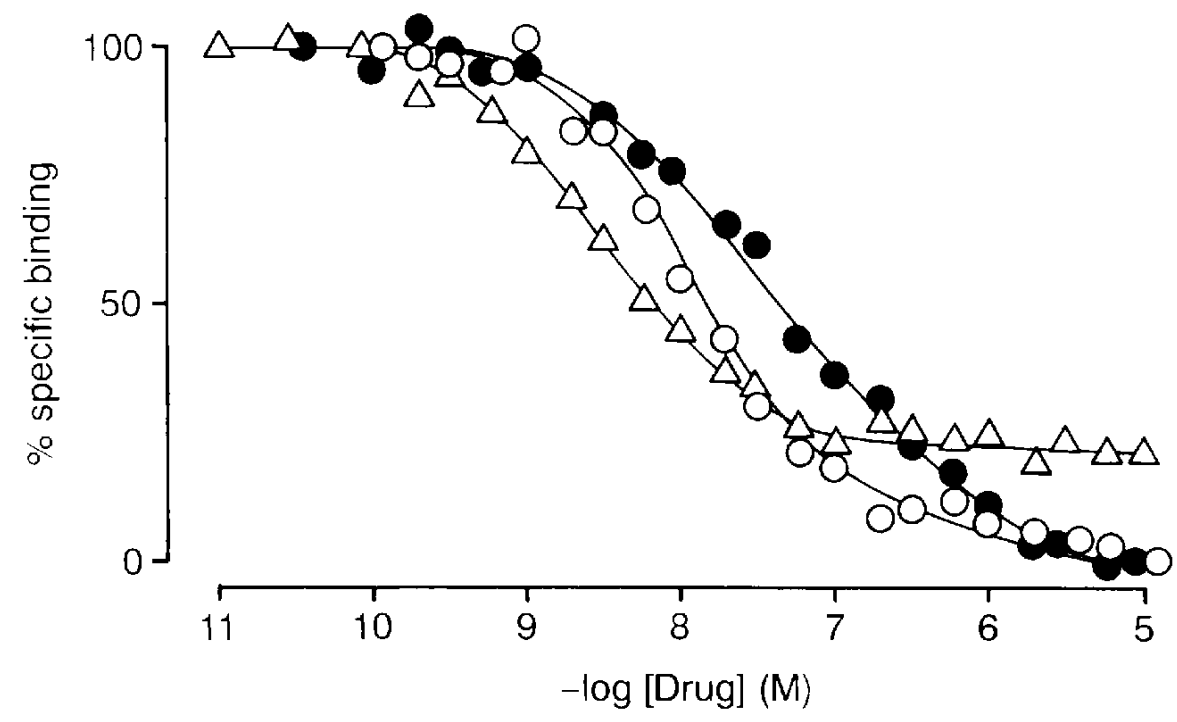

Fig. 1. Inhibition of ${ }^{3} \mathrm{H}-p$-aminoclonidine (PAC) binding to rat kidney membranes by tizanidine (O), clonidine ( $\left.\bigcirc\right)$ and adrenaline $(\triangle) .{ }^{3} \mathrm{H}-\mathrm{PAC}(1 \mathrm{nM})$ was incubated with various concentrations of competing drugs under the assay conditions described in Methods. The figure represents a single experiment for cach drug, where cach point is the mean of duplicatc determinations.

Table 1. Inhibition of ${ }^{3} \mathrm{H}-p$-aminoclonidine binding to rat renal membranes by competing drugs

\begin{tabular}{|c|c|c|c|c|c|}
\hline Drug & $\mathrm{n}$ & $\begin{array}{l}\text { Imidazoline- } \\
\text { receptors } \\
\mathrm{K}_{\mathrm{i}}(\mathrm{nM})\end{array}$ & $\begin{array}{c}\alpha_{2} \text {-Receptors } \\
\mathrm{K}_{\mathrm{i}}(\mathrm{nM})\end{array}$ & Ratio & $\% \alpha_{2}$ \\
\hline Tizanidine & 4 & $4.17 \pm 1.81$ & $91.5 \pm 9.1$ & 0.046 & 71 \\
\hline Clonidine & 4 & $9.20 \pm 1.23$ & $9.20 \pm 1.23$ & 1.0 & $\ldots$ \\
\hline Oxymethazoline & 3 & $2.28 \pm 0.36$ & $25.9 \pm 5.5$ & 0.088 & 70 \\
\hline Naphazoline & 4 & $309 \pm 26$ & $2.13 \pm 0.33$ & 145.0 & 81 \\
\hline Adrenaline & 4 & $>10000$ & $3.18 \pm 0.41$ & $>3000$ & 82 \\
\hline
\end{tabular}

Ratio represents the $\mathbf{K}_{\mathrm{i}}$ value for imidazoline-receptor divided by that for $\alpha_{2}$-adrenoceptor. $\% \alpha_{2}$ means the proportion of $\alpha_{2}$-adrenoceptors in the total specific binding sites. ${ }^{a}$ : not discriminated. 


\section{DISCUSSION}

The present study confirms the previous observations that ${ }^{3} \mathrm{H}-\mathrm{PAC}$ binding sites of rat kidney membranes consist of two distinct populations (9). Both sites can be discriminated by their different affinities to adrenaline or imidazoline compounds. One type of site is $\alpha_{2}$-adrenoceptors which are sensitive to adrenaline and make up $70-80 \%$ of the total ${ }^{3} \mathrm{H}-\mathrm{PAC}$ binding sites, while another population corresponds to imidazoline-receptors insensitive to adrenaline.

Tizanidine and oxymetazoline show higher affinity to imidazoline-receptors as compared with $\alpha_{2}$-adrenoceptor. On the other hand, clonidine cannot discriminate between the two receptor types, and naphazoline shows a high sclectivity to $\alpha_{2}$-adrenoceptors. Therefore, tizanidine is the most selective ligand for the imidazoline-receptor among the compounds tested.

Wide distribution of imidazoline-receptors has been demonstrated in the central nervous system and the periphery $(5-7)$. The physiological functions are still unclear, although the possible involvement of the receptors of the medulla oblongata in hypotensive response has been demonstrated. Recently, prejunctional inhibitory action through imidazoline-rcceptors has been found in the sympathetic nerve terminals of the rabbit pulmonary artery and thoracic aorta (10). Imidazoline-receptors are also highly sensitive to an endogenous clonidine-displacing substance $(6,9)$. These evidence suggest that imidazoline-receptor-selective drugs such as tizanidine may cause unique pharmacological actions in addition to their actions on $\alpha_{2}$-adrenoceptors (5).

\section{Acknowledgment}

We thank Ms. N. Aoki for secretarial assistance.

\section{REFERENCES}

1 Coward, D.M., Davies, J., Herrling, P. and Rüdeberg, C.: Pharmacological properties of tizanidine (DS103-282). In Die Klinische Wertung der Spastizität, Edited by Conrad, B., Benecke, R. and Bauer, H.J., p. 61-65, Schattauer, Stuttgart (1984) (in German)

2 Palmeri, A. and Wiesendanger, M.: Concomitant depression of locus coeruleus neurons and of flexor reflexes by an $\alpha_{2}$ adrenergic agonist in rats: a possible mechanism for an $\alpha_{2^{-}}$ mediated muscle relaxation. Neuroscience 34, 177-187 (1990)

3 Bousquet, P., Feldman, J, and Schwartz, J.: Central cardiovascular effects of $\alpha$-adrenergic drugs: differences between catecholamines and imidazolines. J. Pharmacol. Exp. Ther. 230, 232 - 236 (1984)

4 Ernsberger, P., Meeley, M.P., Mann, J.J. and Reis, D.J.: Clonidinc binds to imidazole binding sites as well as $\alpha_{2}$-adrenoceptors in the ventrolateral medulla. Eur. J. Pharmacol. 134, 1 - 13 (1987)

5 Lehmann, J., Kvenig-Bérard, E. and Vitou, P.: The imidazoline-preferring receptor. Life Sci. 45, 1609-1615 (1989)

6 Atlas, D.: Clonidine-displacing substance (CDS) and its putative imidazoline receptor. Biochem. Pharmacol. 41, 1541 1549 (1991)

7 Vos, H.D., Convents, A., Keyser, J.D., Backer, J.-P.D., Megen, I.J.B.V., Ebinger, G. and Vauquelin, G.: Autoradiographic distribution of $\alpha_{2}$ adrenoceptors, NAIBS, and 5$\mathrm{HT}_{1 \mathrm{~A}}$ receptors in human brain using $\left[{ }^{3} \mathrm{H}\right]$ idazoxan and ${ }^{3}$ H]rauwolscine. Brain Res. 566, 13-20 (1991)

8 Oshita, M., Kigoshi, S, and Muramatsu, I.: Three distinct binding sites for $\left[{ }^{3} \mathrm{H}\right]$-prazosin in the rat cerebral cortex. $\mathrm{Br}$. J. Pharmacol. 104, 961-965 (1991)

9 Ernsberger, P., Freinland, G., Meeley, M.P. and Reis, D.J.: Characterization and visualization of clonidine-sensitive imidazole sites in rat kidney which recognize clonidine-displacing substance. Am. J. Hypertens. 3, 90-97 (1990)

10 Göthert, M. and Molderings, G.J.: Involvement of presynaptic imidazoline receptors in the $\alpha_{2}$-adrenoceptor-independent inhibition of noradrenaline release by imidazoline derivatives. Naunyn Schmiedebergs Arch. Pharmacol. 343, 271-282 (1991) 